\title{
Successful Management of Uterovaginal Prolapse During the Second Trimester of Pregnancy Using Vaginal Pessary: A Case Report
}

\section{Gebeliğin İkinci Döneminde Gözlenen Uterus Prolapsusun Pesser Halkası ile Başarılı Yönetimi: Olgu Sunumu}

(1) Çağlar Helvacıoğlu, (D) Benan Kahraman Ersoy

University of Health Sciences Turkey, İstanbul Training and Research Hospital, Clinic of Gynecology and Obstetrics, İstanbul, Turkey

\begin{abstract}
Pelvic organ prolapse rarely occurs during pregnancy. Its aetiology is not well understood and it can complicate pregnancy. A 36-year-old multigravida patient developed uterovaginal prolapse in the second trimester of her pregnancy and was managed successfully with the pessaries ring. There are conservative approaches and surgical options in the treatment of prolapse. Pessary ring is a safe treatment option and should be considered before surgical options in the treatment of pelvic organ prolapse.
\end{abstract}

Keywords: Pelvic organ prolapse, pregnancy, pessaries, pelvic floor

\section{öZ}

Gebelik sırasında uterin prolapsus nadiren gözükür. Etiyolojisi tam olarak bilinmemektedir. Gebelikte gözlenen prolapsus gebeliği komplike hale getirebilir. Otuz altı yașında multipar hastanın, gebeliğinin 2. trimesterında total uterin prolapsus gelişmiş olup pesser halkası ile sorunsuz tedavi edilmiştir. Prolapsus tedavisinde konservatif yaklașımlar ve cerrahi seçenekler vardır. Pesser halkası güvenli bir tedavi seçeneğidir. Prolapsus tedavisinde cerrahi seçeneklerden önce pesser halkası akılda tutulmalıdır.

Anahtar Kelimeler: Uterus prolapsus, gebelik, vajinal ilaçlar, pelvik taban

\section{Introduction}

Pelvic organ prolapse (POP) is a common disorder affecting up to $30 \%$ of ageing women. However, uterine prolapse during pregnancy is rare and has an incidence of 1 per 10,000-15,000 deliveries (1,2). Uterine prolapse may complicate pregnancy by causing patient discomfort, cervical ulceration, urinary and genital tract infections, abortion, foetomaternal sepsis and maternal death. Its management depends on the gestational age and experience and varies from a conservative approach to a laparotomic or minimally invasive treatment (3).

The pessary ring is generally preferred in the non-surgical treatment of uterine prolapse during pregnancy. Pessaries-have different shapes and sizes (such as Ring, Gehrung, Gellhorn, Shaatz, Donut, Cube, Inflatoball etc), and the silicone ring pessary is more comfortable for self- insertion and removal (4).

Herein, we present a case of uterovaginal prolapse complicating a 16week pregnancy, which was managed successfully using a vaginal pessary.

\section{Case Report}

A 36-year-old multigravida woman presented to the obstetrics clinic with cervical prolapse in the $16^{\text {th }}$ week of gestation (Figure 1). This was her third pregnancy and she had two previous vaginal deliveries without any complications. In addition, she had no complaints during her previous pregnancies, and had no history of POP, constipation, chronic cough or pelvic trauma. On transvaginal ultrasound, the cervical length was 45 $\mathrm{mm}$ and the entire cervix was observed to be outside of the vulva. The cervical mucosa was oedematous and ulcerated. POP was classified as follows: uterine prolapse POP-Q 4. After repositioning the uterus with a pessary ring, we found a cystocele POP-Q 1. Her cervical prolapse was successfully restored to the pelvic cavity in the supine position. An obstetric ultrasonography was performed and a live, apparently normal, 16 weeks +3 days foetus was seen. The amniotic fluid index measurement was also normal.

Antibiotherapy (amoxicillin-clavulanate $1000 \mathrm{mg}$ treatment for one week) was started for the cervicovaginal infection. Vaginal pessary was
Address for Correspondence/Yazıșma Adresi: Çağlar Helvacıoğlu MD, University of Health Sciences Turkey, İstanbul Training and Research Hospital, Clinic of Gynecology and Obstetrics, İstanbul, Turkey

Phone: +90 5059533648 E-mail: caglarhel@hotmail.com ORCID ID: orcid.org/0000-0002-6247-2383

Cite this article as/Atıf: Helvacıoğlu Ç, Kahraman Ersoy B. Successful Management of Uterovaginal Prolapse During the Second Trimester of Pregnancy Using Vaginal Pessary: A Case Report. İstanbul Med J 2020; 21(6): 481-483.

(C) Copyright 2020 by the University of Health Sciences Turkey, Istanbul Training and Research Hospital/Istanbul Medical Journal published by Galenos Publishing House

(C) Telif Hakkı 2020 Sağlık Bilimleri Üniversitesi istanbul Ĕgitim ve Araştırma Hastanesi/Istanbul Tıp Dergisi, Galenos Yayınevi tarafından basılmıștır.
Received/Geliș Tarihi: 13.04.2020 Accepted/Kabul Tarihi: 24.09.2020 
recommended to prevent uterine prolapse. A silicone ring-shaped size 11 (0-13) vaginal pessary was inserted into the vagina (Figure 2). Once the pessary ring was inserted, the cervix remained intravaginal and the patient had no urinary retention complaint. She was advised to continue her routine daily activities and bed rest was not recommended. The patient was monitored weekly and the vaginal pessary was removed, cleaned and re-inserted at each control visit. The prolapse resolved spontaneously POP-Q 1 in the $24^{\text {th }}$ week and the patient did not use the pessary again. The antepartum follow-up was normal and no further complications occurred during pregnancy. There was no vaginal or cervical ulceration and the old cervical ulcerations healed with the help of the vaginal pessary.

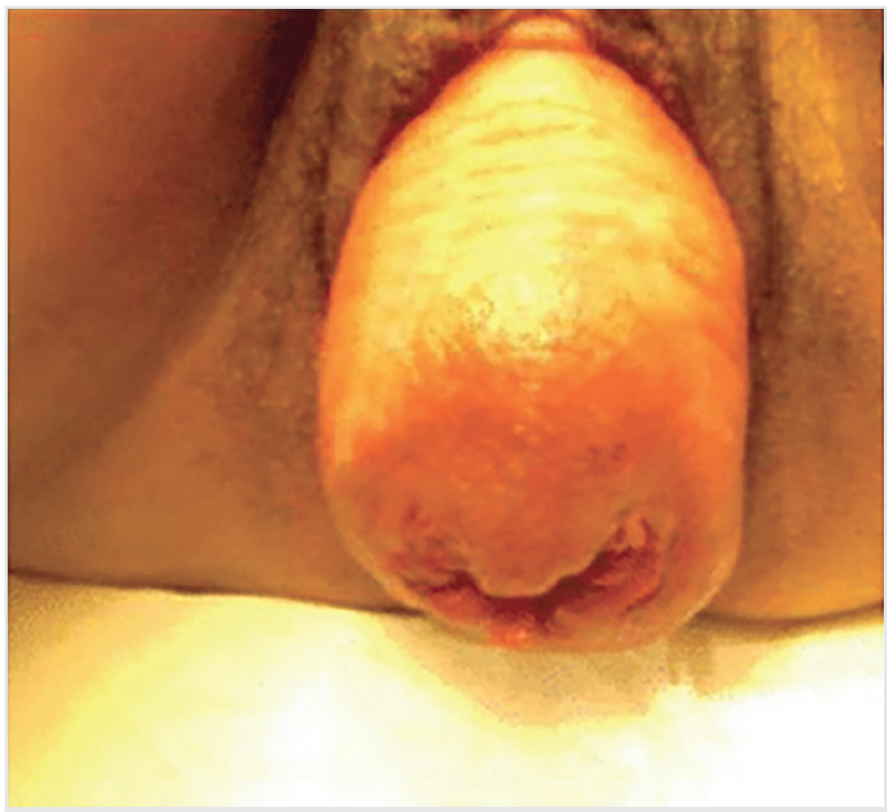

Figure 1. Uterovaginal prolapse at 16 weeks of gestation

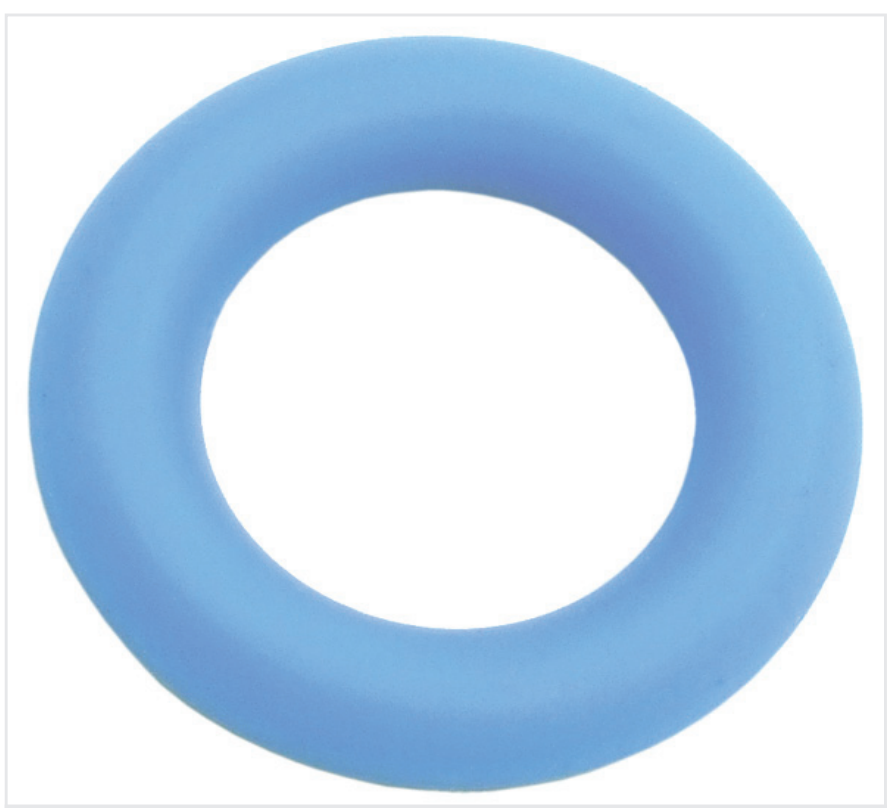

Figure 2. The silicone ring pessary
The patient had a spontaneous vaginal delivery at 40 weeks +4 days of a healthy baby weighing 3,800 gr, length $50 \mathrm{~cm}$, and the APGAR scores at the first and fifth minutes were 7 and 8, respectively. After birth, no POP was observed and the patient was discharged with no complications. No problems were encountered during the puerperal period. A further examination at three months postpartum showed no evidence of any prolapse.

Informed consent was obtained from the patient.

\section{Discussion}

Although POP occurs with ageing, it is very rare during pregnancy. Many risk factors are associated with the development of prolapse during pregnancy. Parity, ethnicity, delivery type, the interval between consecutive pregnancies, connective tissue diseases, increased strain on the support of the uterus, physiologic changes of pregnancy and past history of prolapse are among the most common risk factors (5). In this case, cervical prolapse occurred in the second trimester of pregnancy. We think that hormonal changes, especially progesterone and relaxin, lead to the growth and softening of the cervix.

POP during pregnancy can cause antepartum, intrapartum and puerperal complications. Antepartum complications can result in abortion, urinary and genital tract infections, acute urinary retention, preterm labour and even maternal death. Major intrapartum complications include an inability to attain adequate cervical dilatation, cervical laceration, obstructive labour, hysterorrhexis at the lower uterine segment, foetal death and maternal morbidity. Puerperal infection and postpartum haemorrhage due to uterine atony are common consequences of uterine prolapse after delivery (3).

The management strategies vary depending on the clinical conditions and experience. In the literature, there are two different types of management approaches, including conservative and surgical management $(3,4)$. Conservative management consists of gynaecological hygiene and bed rest in a slight Trendelenburg position (5). In addition, vaginal pessaries can be used in POP and be easily applied. Common complications of vaginal pessaries include vaginal discharge, odour, mucosal erosion and abrasions of the vagina and urinary retention (4). In this patient, we preferred the pessary ring and did not encounter any of these complications. The pessary ring size was no: 11 and perfectly fitted into the patient. She learned how to use the pessary by herself and perfectly adapted to the procedure. Therefore, selection of the size and shape of the ring and the patient's compatibility affects the success of the procedure.

In general, any surgery during pregnancy can lead to both foetal and maternal morbidity. Cases that were managed with abdominal laparotomic and laparoscopic methods have been reported in the literature. Particularly, for women who do not desire future pregnancies, concomitant caesarean hysterectomy with abdominal sacrocolpopexy may be a good option. Currently, the surgical approach for prolapse using laparoscopy is widely used and laparoscopic uterine suspension surgeries have been reported across the globe. However, the success of the laparoscopy depends on the surgeon, and procedure should be performed in experienced hands, since several failed laparoscopic 
uterine suspension cases have been encountered (6). Treatment strategies should aim to improve foeto-maternal health and patient comfort. In this case, we successfully managed the uterine prolapse with a silicone pessary ring and avoided all complications.

In conclusion, POP rarely occurs during pregnancy; however, it may complicate pregnancy. Pessary rings are an effective and a reliable method for treatment and should be considered before surgical alternatives.

\section{Ethics}

Informed Consent: Informed consent was obtained from the patient.

Peer-review: Externally peer-reviewed.

Authorship Contributions: Surgical and Medical Practices - C..H.; Concept - B.K.E.; Design - B.K.E.; Data Collection or Processing - B.K.E.; Analysis or Interpretation - C..H.; Literature Search - Ç.H.; Writing- B.K.E.

Conflict of Interest: No conflict of interest was declared by the authors.

Financial Disclosure: The authors declared that this study received no financial support.

\section{References}

1. Samuelsson EC, Arne Victor FT, Tibblin G, Svardsudd KF. Signs of genital prolapse in a Swedish population of women 20 to 59 years of age and possible related factors. Am J Obstet Gynecol 1999; 180: 299-305.

2. Guariglia L, Carducci B, Botta A, Ferrazzani S, Caruso A. Uterine prolapse in pregnancy. Gynecol Obstet Invest 2005; 60: 192-4.

3. Tsikouras P, Dafopoulos A, Vrachnis N, Iliodromiti Z, Bouchlariotou S, Pinidi $P$, et al. Uterine prolapse in pregnancy: risk factors, complications and management. J Matern Fetal Neonatal Med 2014; 27: 297-302.

4. Ding J, Song XC, Deng M, Zhu L. Which factors should be considered in choosing pessary type and size for pelvic organ prolapse patients in a fitting trial? Int Urogynecol J 2016; 27: 1867-71.

5. Daskalakis G, Lymberopoulos E, Anastasakis E, Kalmantis K, Athanasaki A, Manoli A, et al. Uterine prolapse complicating pregnancy. Arch Gynecol Obstet 2007; 276: 391-2.

6. O'Brien PM, Ibrahim J. Failure of laparoscopic uterine suspension to provide a lasting cure for uterovaginal prolapse. Br J Obstet Gynaecol 1994; 101: 707-8. 